\title{
28 Research Square \\ Undernutrition and Associated Factors Among Lactating Women in Dire Dawa Health Facilities, Ethiopia
}

Zerihun Tariku ( $\square$ zerihun.tariku@ddu.edu.et )

Dire Dawa university

Bereket Tefera

Dire Dawa university

Serawit Samuel

Dire Dawa university

Tariku Derese

Dire Dawa university

Melese Markos

Dire Dawa university

Samuel Dessu

Dire Dawa university

Research Article

Keywords: Undernutrition, lactating, Dire Dawa, Ethiopia

Posted Date: October 6th, 2020

DOl: https://doi.org/10.21203/rs.3.rs-88070/v1

License: (1) This work is licensed under a Creative Commons Attribution 4.0 International License.

Read Full License 


\section{Abstract}

Background: The nutritional status of lactating women is very important since it also affects the health of their children. However, there was limited information on maternal nutrition status in low-income countries like Ethiopia, especially in the study area.

Objectives: Determine magnitude of undernutrition and associated factors among lactating women

Methods: Institutional based cross-sectional study was conducted among 422 lactating women in Dire Dawa town health facilities from February 10/02/2019 - March 30/ 03/2019.

Result: Prevalence of undernutrition was $22 \%$. Women who age 15-25 years were four times more likely undernourished than older [AOR=4.04(Cl: $(1.74,9.40)]$. Unable to read and write Women were almost five times more likely to be undernourished than formal education [AOR=4.76 Cl: $(2.31,9.81)]$. Women who have family size $>7$ were six times more likely to be undernourished than family size $<3$ [AOR=5.53 $\mathrm{Cl}:($ $1.15,26.53)]$. Women not take additional food during lactating were 4.5 times more likely undernourished than take additional food $[A O R=4.56 \mathrm{Cl}(1.50,13.9)]$. DD score $<5$ were four times more likely to be undernourished than $(>=5)$ DD [AOR= $4 \mathrm{Cl}:(2.02,7.90)]$.

Conclusion: Prevalence of undernutrition in the study area was high: Factors associated with underweight were: Age of lactating women, Education status, Family size, Additional food during lactation and DD score. Thus, multi-sectoral collaboration targeted at improving women's educational status and increasing food during lactation need to be emphasized.

\section{Background}

Undernutrition and its associated disease conditions can be caused by eating too little, or eating an unbalanced diet that lacks necessary nutrients. Undernutrition, defined as failure to consume adequate energy, protein, and micronutrients to meet basic requirements for body maintenance, growth, and development (UNICEF, 2011). Undernutrition is one of the most devastating problems worldwide and is inextricably linked with poverty (IYCF, 2011).

Women are more likely to suffer from nutritional deficiency than men including their reproductive biology, low social status, poverty and lack of education. Physiologically, women are more likely to be undernourished, especially if they are menstruating, pregnant, or lactating (Black.RE et al., 2013). In addition, socio-cultural traditions and disparities in household work patterns can also increase women's chance of being undernourished (Ransom IE and KL, 2013).

Nutrition throughout life has a major effect on health. This is true for lactating women as adequate maternal nutrition is one of the best ways to ensure maternal and fetal wellbeing in developed and developing countries (IYCF,2011).Diet quality in the first 1000 days of life, is fundamental for physical and mental development as well as maintaining good health in later life. Large segment of worlds' 
population being undernourished or have low mineral and vitamin status due to lack of availability or inability to access to food of quality of diet. So providing a nourishing diet for pregnant and lactating mother results in significantly better infant health outcomes (WHO, 2014).

Lactating women produce between 700 to $800 \mathrm{ml}$ of milk per day. This needs an extra 500 kilocalories energy provision per day in additional to normal 2200 kilocalories (Patricia, 2014). Breast milk is rich in the vitamins and minerals needed to protect an infant's health and promote growth and development. If the mother's diet is poorly diversified, the levels of micronutrients in breast milk may be reduced or the mother's own health may be affected (Allen, 2000).

Adequate nutrition during lactation is not only important for optimum growth, maturation, mental development, physical wellbeing and disease resistance, but also breaks the intergenerational link of malnutrition and the transmission of its harmful effect to the succeeding generation through women and their children (Gala.U.M et al., 2016, Gemeda et al., 2013).

In Sub-Saharan Africa (SSA), undernutrition during pregnancy and lactation is a widespread problem due to monotonous, plant based diet which does not meet the requirement. (Imamura et al. 2015). Even when enough food is available, the majority of women do not receive adequate nutrients during pregnancy and lactation attributable to poor knowledge on what constitutes an adequate diet (Ahmed et al., 2012).

\section{Methods}

\section{Study Area and Period}

The study was conducted in Dire Dawa city administration which is located in the Eastern part of the Ethiopia. According to the Ethiopian central statistics authority's 2008 report, Dire Dawa administrative region has total population of 453,000 of whom almost one to one male to female ratio. It is situated $515 \mathrm{Kms}$ from Addis Ababa. Dire Dawa city administration is one of the two City Administration and majority of its population lives in urban area with 233,224 or around $68.22 \%$ of the population are urban inhabitants. The public health organizations which are involved in health care delivery include 1public referral hospital, 1 public district hospital and 8 public health centers. All health institutions provide maternal health service in addition to other service. The study was conducted from February 10/02/2019 - March 30/ 03/2019.

\section{Study Design}

Institutional based cross sectional study design was used.

\section{Population}

\section{Source population}


All lactating mothers living in Dire dawa City who were visiting Dire Dawa Health facilities for postnatal care and EPI program was considered as the source of population.

\section{Study population}

Selected lactating mothers who visiting Dire dawa Hospitals and Health Centers for postnatal care and EPI program during data collection period were considered as study population.

\section{Inclusion and exclusion criteria}

\section{Inclusion Criteria}

Those lactating mothers living in Dire Dawa City and who was visiting at Dire dawa Hospitals and Health centers for post-natal care and EPI program during the study period.

\section{Exclusion Criteria}

Lactating women who were critical ill, pregnant and physical deformity will be excluded from the study to improve quality of anthropometric measurements.

\section{Data collection instrument}

Data on socio demographic, dietary diversity and food security variables were collected by using structured pretested Amharic version questionnaires adapted from different literature review (Eshetu et al., 2017, Kiday et al., 2013a, Mihiretu et al., 2015, Temesgen et al., 2015). The adapted data collection tools prepared in English will be translated to Amharic language and again back to English to check consistency.

Food security was assessed using Household Food Insecurity Access Scale (HFIAS), it validated tool use in the Ethiopian context (Seifu et al., 2015). The HFIAS has nine questions asking household's last month experience about three domains of food insecurity: feeling uncertainty of food supply, insufficient quality of food, and insufficient food intake and its physical consequences. (Coates et al., 2007).

The mother's dietary intake pattern will be measured by a qualitative recall of all foods consumed by each woman during the previous 24 hours. Thus, certain food groups was aggregated to calculate Individual (women) dietary diversity score (WDDS) and the mean DDS will be used to classify mothers food intake as adequate or not (Kennedy et al., 2013).

To measure the outcome variable, anthropometric measurement (weight) of lactating women were measured to the nearest $100 \mathrm{~g}$ using portable electronic digital scale (Seca, Germany model) and height will be measured to the nearest $0.1 \mathrm{~cm}$ using a portable wooden height measuring board with sliding head bar through standard anthropometric measuring technique.

\section{Data collectors and data collection procedures}


The data will be collected by 8 nurses' work in the post-natal and EPI service and the data was collect at exit. Data collectors were trained for two days by principal investigator. Two BSC holders in Nursing or health officer will be recruited and trained for supervising data collectors. Training was given about methods of anthropometric measurement, interviewing technique and filling questionnaires.

To measure weight of mother requested to remove shoe, wear light close and other supportive materials and data collectors were weigh the study participant on calibrated portable digital scale and value will be recorded to the nearest 100 gram or $0.1 \mathrm{~kg}$.

To measure height the study participant was requested to stand erect with their shoulder level, hands was at the side, head, scapulae, buttock and heel were in contact with vertical measuring board with sliding head bar and height value will be recorded to the nearest $0.1 \mathrm{~cm}$. (WHO 2012)

\section{Data quality control}

To assure the quality of the data, structured and pretested questionnaire was used. Pretest of the questionnaire was employed prior to actual data collection period among $5 \%$ of the study sample on one health center not included in this study. The final version of the questionnaire which was prepared in English translated into the local language of the respondents (Amharic language) and again translated back to English. The data collectors and supervisors were given two day intensive training by principal investigator $(\mathrm{Pl})$ on the instruments, method of data collection, how to take anthropometric measurements and ethical issues.

Relative Technical error Measurement (\%TEM) was done to minimize the random anthropometric measurement errors and relative TEMs for intra and inter examiners for weight and height was acceptable if relative technical error Measurement less than $1.5 \%$ and $2 \%$ respectively (Perini. et al., 2005). Functionality of digital weight scales will be checked using known weight every morning before data collection begin and before every weight measurement the data collectors were assure the scale reading exactly at zero (NHANES, 2007).

Intensive supervision were done by principal investigator and supervisor and they were check the collected data for completeness, accuracy, and consistency throughout the data collection period. The overall supervision was done by the principal investigator. Data double entry was used to make comparisons of two data cells and resolve if there is some difference.

\section{Data processing and analysis}

Data was coded and entered on to Epi-data version 3.0 and exported to SPSS Version 22 for analysis. Missing values checked by conducting simple frequency analysis. Exploratory data analysis was done to check missing values, potential outliers and the normality distribution for those continuous variables.

Body mass index of the mother was calculated through weight in kilogram divided by square of height in meters and based on the result mother was categorized in to underweight with BMI less than $18.5 \mathrm{~kg} / \mathrm{m} 2$, 
normal those having BMI $18.5-24.99 \mathrm{~kg} / \mathrm{m} 2$, overweight with BMI $25-29.99 \mathrm{~kg} / \mathrm{m} 2$ and obese those having BMI greater than or equal to $30 \mathrm{~kg} / \mathrm{m} 2$ (WHO 2012). Since the interest was identifying lactating women at risk of undernutrition, the dependent variables are coded as 1 lactating women were undernourished $(\mathrm{BMl}<18.5 \mathrm{~kg} / \mathrm{m} 2)$ and coded as 0 if not.

Multi-Collinearity effect was checked and variables with SE $>2$ was removed from analysis and those variables have no collinear effect was included in binary logistic regression model to see the possible relationships with the outcome variables. Covariates with a p-value less than 0.25 in the bivariable logistic regression analysis was candidate for a multivariable logistic regression analysis to control potential confounders and to identify associated factors of undernutrition. The fitness of the model was tested by Hosmer- Lemeshow goodness of fit test ( $p$-value $=0.83$ ). Odd Ratios along with $95 \%$ Confidence interval was estimated measure the strength of the association. Level of statistical significance was declared at $p$-value less 0.05 . Results were presented using frequencies, summary measures, tables, and figures.

\section{Results}

\section{Socio-demographic characteristics of study participants}

A total of 401 lactating women aged 15-49 were interviewed, with a response rate of $95 \%$. Almost half, $329(49.4 \%)$ of the respondents were in the age group of $26-35$ years. The mean ( \pm SD) age of respondents were $28.7( \pm 6.2)$ years. Majority, 569 (93.1\%) of study participants were married. one hundred eighty-nine (47.1\%) lactating women were orthodox religion followers. Regarding to education status, 59 (14.7\%) women and 48 (12\%) husband, were not able to read and write. From the total study participant, $162(40.4 \%)$ lactating women were housewife. Majority, $323(80.5 \%)$ of the study participants lived in male-headed households. More than one fourth, 119 (29.6\%) study participants have family size seven and more than seven. (Table 1)

Table 1: Socio-demographic characteristics of lactating women whose age is $15-49$ years in in Dire Dawa town, Eastern Ethiopia, 2019/20 ( $\mathrm{n}=401)$ 


\begin{tabular}{|c|c|c|c|}
\hline Variables & Category & Frequency & Percent \\
\hline \multirow[t]{3}{*}{ Age of lactating women } & $15-25$ year & 149 & 37.2 \\
\hline & 26-35 year & 176 & 43.9 \\
\hline & $36-49$ year & 75 & 18.7 \\
\hline \multirow[t]{2}{*}{ Current marital status of women } & Married & 368 & 91.8 \\
\hline & Other* & 33 & 8.2 \\
\hline \multirow[t]{3}{*}{ Religion of women } & Orthodox & 189 & 47.1 \\
\hline & Muslim & 134 & 33.4 \\
\hline & Protestant & 78 & 19.5 \\
\hline \multirow[t]{5}{*}{ Education of women } & Unable to read and right & 59 & 14.7 \\
\hline & Able to read and write & 103 & 25.7 \\
\hline & Only primary & 91 & 22.7 \\
\hline & Secondary & 107 & 26.7 \\
\hline & College diploma and above & 41 & 10.2 \\
\hline \multirow[t]{5}{*}{ Education of husband } & Unable to read and right & 48 & 12.0 \\
\hline & Able to read and write & 64 & 16.0 \\
\hline & Only primary & 85 & 21.2 \\
\hline & Secondary & 147 & 36.6 \\
\hline & College diploma and above & 57 & 14.2 \\
\hline \multirow[t]{4}{*}{ Occupation of women } & Housewife & 162 & 40.4 \\
\hline & Daily labor & 51 & 12.7 \\
\hline & Private employee & 67 & 16.7 \\
\hline & Government employee & 121 & 30.2 \\
\hline \multirow[t]{3}{*}{ Occupation of husband } & Daily labor & 146 & 36.4 \\
\hline & Private employee & 78 & 19.5 \\
\hline & Government employee & 177 & 44.1 \\
\hline \multirow[t]{2}{*}{ Head of the house hold } & Male & 323 & 80.5 \\
\hline & Female & 78 & 19.5 \\
\hline Family size & $1-3$ & 76 & 19.0 \\
\hline
\end{tabular}




\begin{tabular}{|lll|}
$4-6$ & 206 & 51.4 \\
\hline$>=7$ & 119 & 29.6 \\
\hline
\end{tabular}

Household Food Security: 107 (26.7 \%) 95\% Cl $(22.4,30.9)$ of the households were food insecure while the remaining $294(73.3 \%) 95 \% \mathrm{Cl}(69.1,77.6)$ were food secured period (Figure 1).

\subsection{Maternal Health Care and Feeding Practices}

Majority, 245 (61.1\%), lactating women received antenatal care (ANC) at least once during their last pregnancy. But 39 (9.7\%) lactating women were not taken ANC follow up during their pregnancy and also only $117(29.2 \%)$ of study subject had ANC visits of greater than or equal to 4 times (which is recommended). 176 (43.9\%) of the study participants had 3-6 previous pregnancies. Only one third (28.4 $\%)$ of the respondent had birth interval $>2$ years for their last delivery. From the total study participants, $96(23.9 \%)$ got their first pregnancy in less than 18 year. More than three fourth (78.8\%) study subject have got nutrition education. Majority, 360(89.8\%) of the study participant did not avoid any food because of cultural/traditional reasons, whereas, only $83(20.7 \%)$ of them were eating additional foods during their lactation period. The mean \pm SD of women dietary diversity score of lactating mothers in the study area was $5 \pm 1.5$, majority of them, $258(64.3 \%)$ had DDS of $>=5$ and $143(35.7 \%)$ lactating women had $<5$ DDS. From the total participant, 102 (25.4\%) of respondents had experienced illness in the past two weeks preceding the study time. Concerning latrine availability, only $33(8.2 \%)$ of households included in this study had no their own latrine (Table 2).

Table 2: Maternal health care and feeding Practices women in Dire Dawa town, Eastern Ethiopia, 2019/20 $(n=401)$ 


\begin{tabular}{|c|c|c|c|}
\hline Variables & Category & Frequency & Percent \\
\hline \multirow[t]{3}{*}{ Breastfeed child age } & 6-11 month & 170 & 42.4 \\
\hline & $12-18$ month & 158 & 39.4 \\
\hline & 19-24 month & 73 & 18.2 \\
\hline \multirow[t]{3}{*}{ Number of ANC visits } & No visit & 39 & 9.7 \\
\hline & $<4$ visit & 245 & 61.1 \\
\hline & $>=4$ visit & 117 & 29.2 \\
\hline \multirow{4}{*}{ Number of pregnancy } & $\leq 2$ Child & 210 & 52.4 \\
\hline & 3-4 Child & 124 & 30.9 \\
\hline & 5-6 Child & 52 & 13.0 \\
\hline & $>6$ Child & 15 & 3.7 \\
\hline \multirow[t]{2}{*}{ Age at first pregnancy } & $<18$ years & 96 & 23.9 \\
\hline & $>=18$ years & 305 & 76.1 \\
\hline \multirow[t]{3}{*}{ Birth interval } & First birth & 85 & 21.2 \\
\hline & 1-2 year & 202 & 50.4 \\
\hline & $>2$ year & 114 & 28.4 \\
\hline \multirow[t]{2}{*}{ Place of delivery } & Health facility & 333 & 83.0 \\
\hline & Home & 68 & 17.0 \\
\hline \multirow[t]{2}{*}{ Nutritional education } & Yes & 316 & 78.8 \\
\hline & No & 85 & 21.2 \\
\hline \multirow[t]{2}{*}{ Number of feeding } & $<3$ feed & 107 & 26.7 \\
\hline & $>=3$ feed & 294 & 73.3 \\
\hline \multirow[t]{2}{*}{ Avoiding food during lactation } & Yes & 41 & 10.2 \\
\hline & No & 360 & 89.8 \\
\hline \multirow[t]{2}{*}{ Additionally food consumption } & Yes & 83 & 20.7 \\
\hline & No & 318 & 79.3 \\
\hline \multirow[t]{2}{*}{ Women dietary diversity } & $<5 \mathrm{DD}$ & 143 & 35.7 \\
\hline & $>=5 \mathrm{DD}$ & 258 & 64.3 \\
\hline History of illness & Yes & 299 & 74.6 \\
\hline
\end{tabular}




\begin{tabular}{|llll|} 
& No & 102 & 25.4 \\
Availability of toilet & Yes & 33 & 8.2 \\
\cline { 2 - 3 } & No & 368 & 91.8 \\
\hline
\end{tabular}

\subsection{Maternal nutritional status}

The nutritional status of lactating women was measured by Body Mass Index (BMI). Accordingly, the mean (+SD) BMI was $21(+2.4) \mathrm{Kg} / \mathrm{m} 2$. From the total study participants, $88(22 \%) ; 95 \% \mathrm{Cl}(18,25.9) \mathrm{had}$ $\mathrm{BMl}$ of $<18.5 \mathrm{Kg} / \mathrm{m} 2$ and $288(71.8 \%) ; 95 \% \mathrm{Cl}(67.6,76.1)$ were in normal range (Figure 2).

\subsection{Factors associated with undernutrition among lactating women}

To determine the association between undernutrition and explanatory variables, bivariate analysis was performed using logistic regression. The result indicates that there is association between nutritional status of lactating women and some of the explanatory variables under the study such as age of lactating women, educational status of women, Age at first pregnancy family size, frequency of ANC visit, birth interval for the index child, additional food during lactation, Number of feeding, women dietary diversity and levels of household food insecurity, and (Table 4).

Lactating women who had $<4$ ANC visit were 1.7 times more likely to be undernourished than those women who had $>=4$ ANC visit $[A O R=1.77,95 \% \mathrm{Cl}$ : $(0.86,3.59)]$. Those lactating women who had $1-2$ years birth interval from index child had 1.24 times more likely undernutrition than those women who had $>2$-year birth interval from index child [AOR $=1.2395 \% \mathrm{Cl}$ : $(0.60,2.50)]$. Those women found in food insecure households had 3 times more likely to be undernourished than women in food secured households [OR= 2.86, 95\% Cl: $(1.74,4.72)$ ]. Even if all these factor (described above) are not significantly associated with outcome variable in the multivariable logistic regression.

In multivariable logistic regression analysis, the covariates: age of lactating women, educational status of women , family size, additional food during lactation and women dietary diversity score were statistically significant at $5 \%$ level of significance and were found to be the predictors of undernutrition among lactating women in the study. Those women who age are 15-25 years four times more likely undernourished than those women age 36 to 49 age during lactating [AOR=4.04(Cl: $(1.74$, 9.40)].Lactating women unable to read and write were almost five times more likely to be undernourished than women who had formal education [AOR=4.76 Cl: $(2.31,9.81)]$.Lactating women who have family size $>7$ were six times more likely to be undernourished than women who have family size less than 3 $[A O R=5.53 \mathrm{Cl}:(1.15,26.53)]$.those women not take additional food during lactating were 4.5 times more likely undernourished than women take additional food during lactating. [AOR=4.56 $\mathrm{Cl}(1.50,13.9)$ ]. Regarding women dietary diversity score, those with dietary diversity score below the mean $(<5)$ were 4 more likely to be undernourished than women with score $>=5$ [AOR= $4 \mathrm{Cl}:(2.02,7.90)]$ (Table 3). 
Table 3: Factors associated with undernutrition among lactating women in Dire Dawa town, Eastern Ethiopia, 2019/2020 ( $n=401)$ 


\begin{tabular}{|c|c|c|c|c|c|}
\hline \multirow[t]{3}{*}{ Covariant } & \multirow[t]{3}{*}{ Category } & \multicolumn{2}{|l|}{ BMI } & \multirow[b]{3}{*}{$\begin{array}{l}\text { COR }(95 \% \\
\text { Cl) }\end{array}$} & \multirow[b]{3}{*}{$\begin{array}{l}\text { AOR } \\
(95 \% \mathrm{Cl})\end{array}$} \\
\hline & & $<18.5$ kg/m2 & $>=18.5$ & & \\
\hline & & Undernutrition & normal & & \\
\hline \multirow{4}{*}{$\begin{array}{l}\text { Age of lactating } \\
\text { Women }\end{array}$} & $15-25$ year & 55 (36.9\%) & $\begin{array}{l}94 \\
(63.1 \%)\end{array}$ & $\begin{array}{l}2.59 \text { (1.33, } \\
5.05)\end{array}$ & $\begin{array}{l}4.04 \\
(1.74\end{array}$ \\
\hline & & & & &  \\
\hline & 26-35 year & $19(10.8 \%)$ & $\begin{array}{l}157 \\
(89.2 \%)\end{array}$ & $\begin{array}{l}0.54 \\
(0.25,1.13)\end{array}$ & $\begin{array}{l}0.71 \\
(0.29 \\
1.61)\end{array}$ \\
\hline & $36-49$ year & $14(18.4 \%)$ & $\begin{array}{l}62 \\
(81.6 \%)\end{array}$ & 1 & 1 \\
\hline \multirow[t]{3}{*}{$\begin{array}{l}\text { Education } \\
\text { status of women }\end{array}$} & $\begin{array}{l}\text { Unable to read } \\
\text { and write }\end{array}$ & $28(47.5 \%)$ & $\begin{array}{l}31 \\
(52.5 \%)\end{array}$ & $\begin{array}{l}5.26(2.82, \\
9.82)\end{array}$ & $\begin{array}{l}4.76 \\
(2.31 \\
9.81)^{\star * *}\end{array}$ \\
\hline & $\begin{array}{l}\text { Able to read and } \\
\text { write }\end{array}$ & $25(24.3 \%)$ & $\begin{array}{l}78 \\
(75.7 \%)\end{array}$ & $\begin{array}{l}1.86(1.05, \\
3.32)\end{array}$ & $\begin{array}{l}1.77 \\
(0.88 \\
3.53)\end{array}$ \\
\hline & $\begin{array}{l}\text { Have formal } \\
\text { education }\end{array}$ & 35 (14.6\%) & $\begin{array}{l}204 \\
(85.4 \%)\end{array}$ & 1 & 1 \\
\hline \multirow[t]{2}{*}{$\begin{array}{l}\text { Age at first } \\
\text { pregnancy }\end{array}$} & $<18$ years & $27(28.1 \%)$ & $\begin{array}{l}69 \\
(71.9 \%)\end{array}$ & $\begin{array}{l}1.56(1.03, \\
2.65)\end{array}$ & $\begin{array}{l}0.92 \\
(0.48 \\
1.75)\end{array}$ \\
\hline & $>=18$ years & $61(20 \%)$ & $244(80 \%)$ & 1 & 1 \\
\hline \multirow[t]{3}{*}{ Family size } & $1-3$ & $12(15.8 \%)$ & $\begin{array}{l}64 \\
(84.2 \%)\end{array}$ & 1 & 1 \\
\hline & $4-6$ & 33 (16.1\%) & $\begin{array}{l}173 \\
(83.9 \%)\end{array}$ & $\begin{array}{l}1.02(0.49, \\
2.09)\end{array}$ & $\begin{array}{l}3.56(0.78 \\
16.24)\end{array}$ \\
\hline & $>=7$ & $43(36.2 \%)$ & $\begin{array}{l}76 \\
(63.8 \%)\end{array}$ & $\begin{array}{l}3.02 \text { (1.47, } \\
6.21)\end{array}$ & $\begin{array}{l}5.53 \\
(1.15 \\
26.53)\end{array}$ \\
\hline \multirow[t]{2}{*}{$\begin{array}{l}\text { Number of } \\
\text { ANC visit }\end{array}$} & $<4$ visit & $70(24.6 \%)$ & $\begin{array}{l}214 \\
(75.4 \%)\end{array}$ & $\begin{array}{l}1.79(1.2 \\
3.18)\end{array}$ & $\begin{array}{l}1.76 \\
(0.86 \\
3.59)\end{array}$ \\
\hline & $>=4$ visit & $18(15.4 \%)$ & $\begin{array}{l}99 \\
(84.6 \%)\end{array}$ & 1 & 1 \\
\hline \multirow[t]{2}{*}{ Birth interval } & first birth & $18(21.2 \%)$ & $\begin{array}{l}67 \\
(78.8 \%)\end{array}$ & $\begin{array}{l}1.34(0.65, \\
2.75)\end{array}$ & $\begin{array}{l}2.73 \\
(0.67 \\
11.22)\end{array}$ \\
\hline & 1-2 year & $51(25.2 \%)$ & $\begin{array}{l}151 \\
(74.8 \%)\end{array}$ & $\begin{array}{l}1.68(0.94, \\
3.03)\end{array}$ & $\begin{array}{l}1.24 \\
(0.60 \\
2.50)\end{array}$ \\
\hline
\end{tabular}




\begin{tabular}{|c|c|c|c|c|c|}
\hline & $>2$ year & $19(16.7 \%)$ & $\begin{array}{l}95 \\
(83.7 \%)\end{array}$ & 1 & 1 \\
\hline \multirow[t]{2}{*}{$\begin{array}{l}\text { additional food during } \\
\text { lactation }\end{array}$} & No & $83(26.1 \%)$ & $\begin{array}{l}235 \\
(73.9 \%)\end{array}$ & $\begin{array}{l}5.51(2.15 \\
14.1)\end{array}$ & $\begin{array}{l}4.56 \\
(1.50 \\
13.9)^{\star *}\end{array}$ \\
\hline & Yes & $5(6.1 \%)$ & $\begin{array}{l}78 \\
(93.9 \%)\end{array}$ & 1 & 1 \\
\hline \multirow[t]{2}{*}{$\begin{array}{l}\text { Number } \\
\text { of feeding }\end{array}$} & $<3$ feed & 37 (34.6\%) & $\begin{array}{l}70 \\
(65.4 \%)\end{array}$ & $\begin{array}{l}2.52(1.53 \\
4.15)\end{array}$ & $\begin{array}{l}0.67 \\
(0.32 \\
1.64)\end{array}$ \\
\hline & $>=3$ feed & $51(17.3 \%)$ & $\begin{array}{l}243 \\
(82.7 \%)\end{array}$ & 1 & 1 \\
\hline \multirow{2}{*}{$\begin{array}{l}\text { Women dietary } \\
\text { Diversity score }\end{array}$} & $<5$ & $58(40.5 \%)$ & $\begin{array}{l}85 \\
(59.5 \%)\end{array}$ & $\begin{array}{l}5.19(3.12, \\
8.60)\end{array}$ & $\begin{array}{l}4(2.02 \\
, 7.90) * \star\end{array}$ \\
\hline & $>=5$ & $30(11.6 \%)$ & $\begin{array}{l}228 \\
(88.4 \%)\end{array}$ & 1 & 1 \\
\hline \multirow{2}{*}{$\begin{array}{l}\text { Household } \\
\text { food security }\end{array}$} & Food in secure & 39 (41.6\%) & $68(58.4 \%)$ & $\begin{array}{l}2.86(1.74 \\
4.72)\end{array}$ & $\begin{array}{l}1.1(0.53, \\
2.11)\end{array}$ \\
\hline & Food secure & 49 (16.9\%) & $\begin{array}{l}245 \\
(83.1 \%)\end{array}$ & 1 & 1 \\
\hline
\end{tabular}

\section{Discussion}

The prevalence of undernutrition was $22 \%$. Age of lactating women, Education status of lactating women (those unable to read and write), Family size, additional food during lactation and women dietary diversity score were significantly associated with undernutrition.

The prevalence of undernutrition (BMI $<18.5 \mathrm{~kg} / \mathrm{m} 2)$ among lactating women in this study was $22 \%$. This prevalence was much closer to the study documented in Ambo district 21.5\% (Eshetu et al., 2017) and Nekemte 20.5\% (Temesgen et al., 2015). It also similar to studies Adama 19.5\% (Biru et al., 2017), Tigray, $24.6 \%$ (Kiday et al., 2013) and also in Amhara region of Wombera district 25.6\% (Sileshi et al., 2017). When this figure is compared with the result of Jimma 40.6\% (Mihiretu et al., 2015) and Bible $41.7 \%$ (Kedir et al., 2015), it is much lower. This discrepancy could probably be attributed to the interventions on maternal health, nutrition and other women empowering programs by the government as well as other non-governmental organizations in the study area and time difference in which the current study was conducted recently after several community-based interventions were undertaken and also due to sample size difference between the studies. 
On the contrary, the prevalence is much higher than studies in Indonesia 9\%, (Madanijah.et al., 2016) Tibet 10.3\% (Wang et al., 2010), Myanmar 11.9\% (Zhao et al., 2014) and Nigeria 5\% (Sanusi and Falana, 2009). The difference in the prevalence might be due to socio-demographic factors like education status of women and economic differences between the studies areas.

The present study has affirmed that age of lactating women was significantly associated with their nutritional status. Mothers within the age group of $15-25$ had four times more likely to be undernourished when compared with those mothers in the age group of 36-49. This is in line with a result from study done in Ambo district indicate that lactating women in age group of 17-25 more exposed to undernutrition than older women (Eshetu et al., 2017). Similarly in Bangladesh and Nepal, younger women in the age group 15-24 were more likely to be undernourished than older women (Rahman et al., 2015) (Bhandari S, et al 2016).

Educational status of lactating women was a factor that predicted their nutritional status in this study. Lactating women who were unable to read and write were five times more likely to be undernourished than those mothers who had formal education. Similar studies from India (Maheshwari1.S et al.2015) and also in Ethiopia Ambo district (Eshetu et al., 2017) also reported that undernourished women were more common among those with no formal education. This might be related with an increased awareness of self-care, health service utilization and recognizing the importance of increasing meal frequency during lactation among educated women.

In this study, statistically significant association was found between the covariate family size index and nutritional status of lactating women. Women from $>7$ family size were 5.53 times more likely to be undernourished than women in the 1-3 family size. This had been also supported by the study from Wombera woreda, Northwest Ethiopia and Nekemte 25.6\% (Sileshi et al., 2017) (Temesgen et al., 2015). This association could be due to the fact that women from family size higher were in difficulties of meeting their dietary requirement, engaged in strenuous works like daily laborer and have minimal health care practice and also food security issue in women with higher family size and related underweight and nutritional depletion of the mother due to successive pregnancies.

Additional food during lactation was another factor associated with undernutrition. Accordingly, women who not got additional food during lactation were 4.56 times more likely to be undernourished compared to those who's got additional food during lactation. This had been also supported by a study done in Tigray (Ismael et al., 2017). This could be because during lactation more energy were required than from normal time even more than from pregnancy time, so if the lactating women did not get adequate food during lactation were more exposed to undernutrition.

Dietary diversity score of studied women was also another factor that affects their nutritional status in this study. Those women whose dietary diversity score below the mean $(<5)$ were four times more likely to be undernourished than women with the score a greater than or equal the mean $(>=5)$, implying that eating diverse food groups as a protective to undernutrition. This finding agrees with a study done in Dedo and Seqa-Chekorsa districts, Jimma Zone (Mihiretu et al., 2015). This might be because women 
with low dietary diversity may not get enough balanced diet which is essential for the human body to be immune and perform metabolic activities and also diversified food reflects dietary quality, improves daily nutrient and energy intake. Lactating women who do not get enough energy and nutrients in their diets risk maternal depletion and exacerbates women undernutrition (Allen LH. 2012).

The current study has the following limitations. An anthropometric measurement error was one of the limitations of this study: To minimize this; data collectors were well trained, standardization of anthropometric measures was done and the instrument was calibrated. Since some of the questions are asking the event that occurs 4 weeks back, there is a possibility that some of the responses might suffer from recall bias and this may affect prevalence estimates. This was minimized by probing the respondents about the event. The strength of this study, it has $96.5 \%$ response rate.

\section{Conclusion And Recommendations}

\section{Conclusion}

The result of this study indicated that prevalence of undernutrition (BMI $<18.5 \mathrm{Kg} / \mathrm{m} 2)$ among lactating women in the study area was high. The predictors of undernutrition among lactating women in the study area were: Education status of lactating women (those unable to read and write), Age of lactating women, Family size, additional food during lactation and women dietary diversity score.

\section{Recommendations}

Based on the finding of this study, the following recommendations were made:

- Should strength sustained health and nutrition education to the women, their families and communities regarding increased food intake, proper dietary practices, and dietary diversification during their lactation time. Should closely work with health extension workers to increase awareness of lactating women on how to improve their own nutritional status.

- They should create strong multisector collaboration targeted at improving women educational status and increasing household food security status.

- Should work with beneficiary programs like safety net complemented with nutritional intervention to food insecure households.

For further studies:

- Furthermore, longitudinal studies should also be conducted for a better understanding of the maternal dietary intake with relating to the nutritional status of lactating women.

\section{Declarations}




\section{Acknowledgement}

First of all, I would like to thanks Dire Dawa University for giving me opportunity to develop this research. I extend my appreciation for staffs of Sabian hospitals, and Gende kore, Goro and Legehare Health centers providing important information and for their unlimited co-operation and also I thank the data collectors, supervisors, study participants, and questionnaire translators; without whom the research would not be done.

\section{Ethical considerations}

Before starting of the data collection process, Dire dawa University School of medicine and college of health sciences Institutional Health Research Ethics Review Committee (IHRERC) was secured by ethical clearance and Dire dawa University was write Official letter to hospital and health centers. Informed voluntary written and signed consent was obtained from each participant after explaining the purpose and benefits of the study. The data collector were trained to respect the culture of the people in these communities throughout the data collection process. Confidentiality of the study participants' information also ensure.

\section{Consent for publication}

- Not applicable

\section{Availability of data and material}

- "Availability of Data and Materials"

\section{Funding}

- All sources of funding for the research was Dire Dawa Univerisity.

\section{Authors' contributions}

- Performed the thematic analysis and wrote the first draft of the manuscript as part of her master's project. LR supervised the analysis and the master's project. All authors read and approved the final manuscript.

\section{Competing interests}

- The authors declare that they have no competing interests.

\section{Abbreviations}

AOR Adjusted Odds Ratio

ANC Ante Natal Care 
BMI Body Mass Index

CED Chronic Energy Deficiency

CSA Central Statistical Agency

DDS Dietary Diversity Score

EDHS Ethiopian Demographic and Health Survey

FAO Food and Agriculture Organization

FMoH Federal Minster of Health

HFIAS Household Food Insecurity Access Scale

TEM Technical Error Measurement

NGOs Non-Governmental Organizations

NHANE National Health And Nutrition Examination Survey

UNICEF United Nation Children's Fund

WHO World Health Organization

\section{References}

1. Abebe Ferede, Firaol Lemessa, Mesfin Tafa and Solomon Sisay 2017. The prevalence of malnutrition and its associated risk factors among women of reproductive age in Ziway Dugda district, Arsi Zone, Oromia Regional State, Ethiopia, Journal of public health 52(13), pp. 1 -8.

2. J, Melmaruvathur.S, Kancheepuram, and Tamilnadu. 2013. Nutritional Status among Lactating Women and predictors of infant weight gain in Rural Area of Wardha, India, Journal of maternal and child health, 15 (3), pp. 1 -8.

3. Allen LH. 2012. vitamins in breast milk: relative importance of maternal status and intake, and effects on infant status and function. Adv Nutr.;3(3): pp. 362-369.

4. T. Sayami, Pukar Thapa, Sayami, Kande and M. R. Banjara 2016. Dietary intake patterns and nutritional status of women of reproductive age in Nepal: findings from a health survey. Archives of.

5. Biru K, Jima.A and Abeya .S 2017. Prevalence of Chronic Energy Malnutrition and Maternal Health Service Utilizations among Lactating Mothers in Adama District, Oromia Region, Eastern Ethiopia, Journal of Food Processing \& Technology, 8(1), pp.1-5.

6. RE, Victora.G, Susan.P Walker, Zulfi. A Parul Christian, Mercedes de Onis, Majid Ezzati, Sally Grantham-McGregor, Joanne Katz, Reynaldo Martorell and Ricardo Uauy 2013. Maternal and child 
undernutrition and overweight in low-income and middle-income countries, Lancet 382(98) pp. 427451.Coates.J, Anne .S and Paula.B 2007. Household Food Insecurity Access Scale (HFIAS) for Measurement of Food Access: Indicator Guide VERSION 3, August 2007.

Fromhttps://www.fantaproject.org/monitoring.../HH-food-insecurity retrieved on October /9/2018

7. CSA 2016.Ethiopia Demographic and Health Survey Addis Ababa, Ethiopia.From;https://dhsprogram.com/pubs/pdf/FR328/FR328.pdf retrieved on October /9/2018

8. Eshetu Zerihun, Gudina Egata, Frehiwot Mesfin. 2016 Under Nutrition and its Associated Factors among Lactating Mothers in Rural Ambo District, West Shewa Zone, Oromia Region, Ethiopia. East African Journal of Health and Biomedical Sciences, Volume 1 (1): pp. 39-48.

9. FAO (Food and Agriculture Organization). 2008. Guidelines for measuring household and individual dietary diversity. (version 4), Rome, Italy. From; (http://www.fao.org/fileadmin/user_upload/waworkshop/docs/FAO-guidelines-2011.pdf) _

10. Fikrewold Habte, Bitew and Daniel Telake 2010. Undernutrition among Women in Ethiopia: RuralUrban Disparity, Calverton, Maryland, USA, ICF Macro, pp. 1-31

11. FMoH 2008-2013. Program implementation manual of national nutrition program NNP, A.A From; moh.gov.et .documentp/.pdf retrieved on October 30/2018

12. U.M, Godhia.M.L and Nandanwar.Y.S 2016. Effect of Maternal Nutritional Status on Birth Outcome, International Journal of Advanced Nutritional and Health Science 4(2), pp. 226-233.

13. Gemeda Daba, Fekadu Beyene, Wondu Garoma and Habtamu Fekadu 2013. Assessment of Nutritional Practices of Pregnant Mothers on Maternal Nutrition and Associated Factors in Guto Gida Woreda, East Wollega Zone, Ethiopia, STAR Journal 2(3), pp. 1-7.

14. C, Oguttu. M and Yande, N. S. 2012. Maternal nutrition in rural Kenya: health and socio-demographic determinants and its association with child nutrition. Maternal and Child Nutrition, 8: 275-286.

15. Ismael Kalayu, Kiday Hailesslasie and Yohannes Adama 2017. Comparison of nutritional status and associated factors of lactating women between lowland and highland communities of District Raya, Alamata, Southern Tigray, Ethiopia, BMC Nutrition, 3(61), pp. 1-12.

16. IYCN 2011. Infant \& Young Child Nutrition Project Literature Review Prepared for the Message and Materials Development Workshop produced through support provided by the United States Agency for International Development, Addis Ababa, Ethiopia. From; iycn.org/files/IYCN-Ethiopia-Literaturereview- retrieved on November 14/2018

17. P 2014. underlying causes of child and maternal malnutrition in the estate sector of Sri Lanka, Journal of South Asian studies, 02(03), pp. 241-255.

18. Kedir Teji Roba, Thomas Connor, Tefera Belachew and Nora Brien 2015. Seasonal variation in nutritional status and anemia among lactating mothers in two agro-ecological zones of rural Ethiopia: A longitudinal study. Nutrition pp 1-6.

19. S, Borne.D and Guy Plasqui 2014. Body composition, water turnover and physical activity among women in Narok County, Kenya, BMC Public Health 14(12), pp. 1-8. 
20. G, Tellier.B. and Claude .M 2010. Guidelines for Measuring Household and Individual Dietary Diversity', From; www.fao.org/3/a-i1983e.pdf retrieved on November 14/2018

21. Kidney Hailesslasie, Afework Mulugeta and Meron Girma., 2013. Feeding practices, nutritional status and associated factors of lactating women in Samre Woreda, South Eastern Zone of Tigray, Ethiopia,

22. S, Rimbawan.R, Dodik.B, Zulaikhah.Z, Nuri.A, Lilis.N, Tonny.S, Laksmi.M and Jacques.B 2016. Nutritional status of lactating women in Bogor district, Indonesia: cross-sectional dietary intake in three economic quintiles and comparison with pre-pregnant women, British Journal of Nutrition

23. S, Brijesh P, Singh.O, Singh and Gupta, P. 2015. Variation in body mass index and their determinants among married women in Uttar Pradesh, International Journal of Health,3 (2), pp. 52-55.

24. R, Balakrishna.N, Arlappa.N, Laxmaiah.2010. Diet and Nutritional Status of Women in India, J.Hum Ecol, 29(3), pp. 165-170.

25. Mesfin Tafa and Jemal Haider; 2013 Effect of modern family planning methods use on the nutritional status of women of reproductive age group at Tena district, Arsi Zone, Ethiopia, an international conference on family planning, A.A, Ethiopia,pp.1-8.

26. Mihiretu Alemayehu, Alemayehu Arga and Abele G.Mariam 2015. Factors Associated with Malnutrition among Lactating Women in Subsistence Farming Households from Dedo and SeqaChekorsa Districts, Jimma Zone, 2014, iiste 5 (21), pp. 1-9.

27. Negassie Berhe, Kebede Haile, Meresa Gebremedhin, Yosef Sibhatu, 2016. Dietary diversity and related factors among lactating women visiting public health facilities in Aksum town, Tigray, Northern Ethiopia, BMC Nutrition 2(38), pp. 2-9.

28. NHANES (National Health and Nutrition Examination Survey). 2007. Anthropometry procedures manual. From;https://www.cdc.gov/nchs/data/nhanes/nhanes_07_08/manual_ retrieved on November

29. Nikolaos KM, Charilaos D, Sci MM, Meropi K, Evangelia M, 2010 Clinical nutrition in practice. Blackwell Publishing Ltd, UK.

30. NNP-II 2013. National Nutrition Programme June 2013 - June 2015 From; fao.org/fileadmin/.../Ethiopia_National_Nutrition_Strategy_. retrieved on October /21/2018

31. U 2014. A study of the nutritional status and dietary intake of lactating women in Umuahia, Nigeria, American Journal of Health Research 2(1), pp. 20-26.

32. A, Glauber.L, Oliveira.D and Ornellas.J 2005. Technical error of measurement in anthropometry. Rev Bras Med Esporte, 11(7), pp 86-90

33. Rahman, S, Mondal.N, Islam.R, Ahmed.K, Karim, R. and Alam.S 2015. Under Weightiness among Ever-married Non-pregnant Women in Bangladesh: A Population-Based Study, Universal Journal of Food and Nutrition Science, 3(2), pp. 29-36.

34. E and Kanbaro.L, 2003. Nutrition of women and Adolescent girls: Why it matters? Population Reference Bureau. www.prb.org/.../2003/NutritionofWomenandAdolescentGirlsWhyltMatters.asp 
35. N, Balakrishna.N, Arlappa.A, Laxmaiah.S and Brahmam.G 2010. Diet and nutritional status of women in India, J Hum Ecol 29(3), pp. 165-170.

36. Saba Abraham, Gebremeskel Miruts and Ashenafi Shumye 2015. The magnitude of chronic energy deficiency and its associated factors among women of reproductive age in the Kunama population, Tigray, Ethiopia, in 2014." BMC Nutrition 1(12), pp1-9.

37. A and Falana.M 2009. The Nutritional Status of Mothers Practicing Breast Feeding In Ibadan, Nigeria, African Journal of Biomedical Research, 12(2), pp. 1-7.

38. Seifu Hagos, Torlief Lunde, Damen H.Mariam and Tassew Woldehanna 2015. Is the adapted Household Food Insecurity Access Scale (HFIAS) developed internationally to measure food insecurity valid in urban and rural households of Ethiopia?, BMC Nutrition, 1(2), pp. 1-10.

39. Sileshi Berihun, Getachew Mullu Kassa and Muluken Teshome 2017. Factors associated with underweight among lactating women in Womberma woreda, Northwest Ethiopia; a cross-sectional

40. Temesgen Jessica, Habtamu Fkadu, Desalege Wirtu and Duncan Kenya Nutritional Status and Associated Factors among Lactating Mothers in Nekemte Referral Hospital and Health Centers, Ethiopia, Food Science and Quality Management 35(24), pp.1-11.

41. UNICEF 2009. Tracking progress on child and maternal nutrition a survival and development priority From,https://www.unicef.org/.../Tracking_Progress_on_Child_and_Maternal_Nutrition

42. UNICEF 2011. United Nations Children's Fund. Programming Guide: Infant and Young Child Feeding. https://www.unicef.org/nutrition/files/Final_IYCF_programming_guide_2011.pdf

43. Z, Dang, S., and Yan, H 2010. Nutrient intakes of rural Tibetan mothers: a cross-sectional survey, BMC Public Health, 10(801), pp. 1-8.

44. WHO 1995. Physical status: The use and interpretation of anthropometry, report of WHO expert committee. WHO technical report series, Geneva. from www.who.int/iris/handle/10665/37003.

45. WHO 2005. Quantifying the health impact at national and local levels, WHO environmental burden of disease series, Geneva. From; who.int/outgrowth/publications/quantifying_health_impact/e. retrieved on October $28 / 2018$

46. WHO 2012. Global Database on Body Mass Index. From; who.int/nutrition/databases/bmi/ retrieved on on November / $02 / 2018$

47. WHO 2014. Comprehensive implementation plan on maternal, infant and young child nutrition. From;who.int/nutrition/publications/CIP_document/en. retrieved on October/19/2018

48. A, Zhang.Y, Li.B, Wang.P, Li.J, Xue.Y, and Gao.H 2014. Prevalence of Anemia and Its Risk Factors Among Lactating Mothers in Myanmar, American Journal of Tropical Medicine and Hygiene.

\section{Figures}




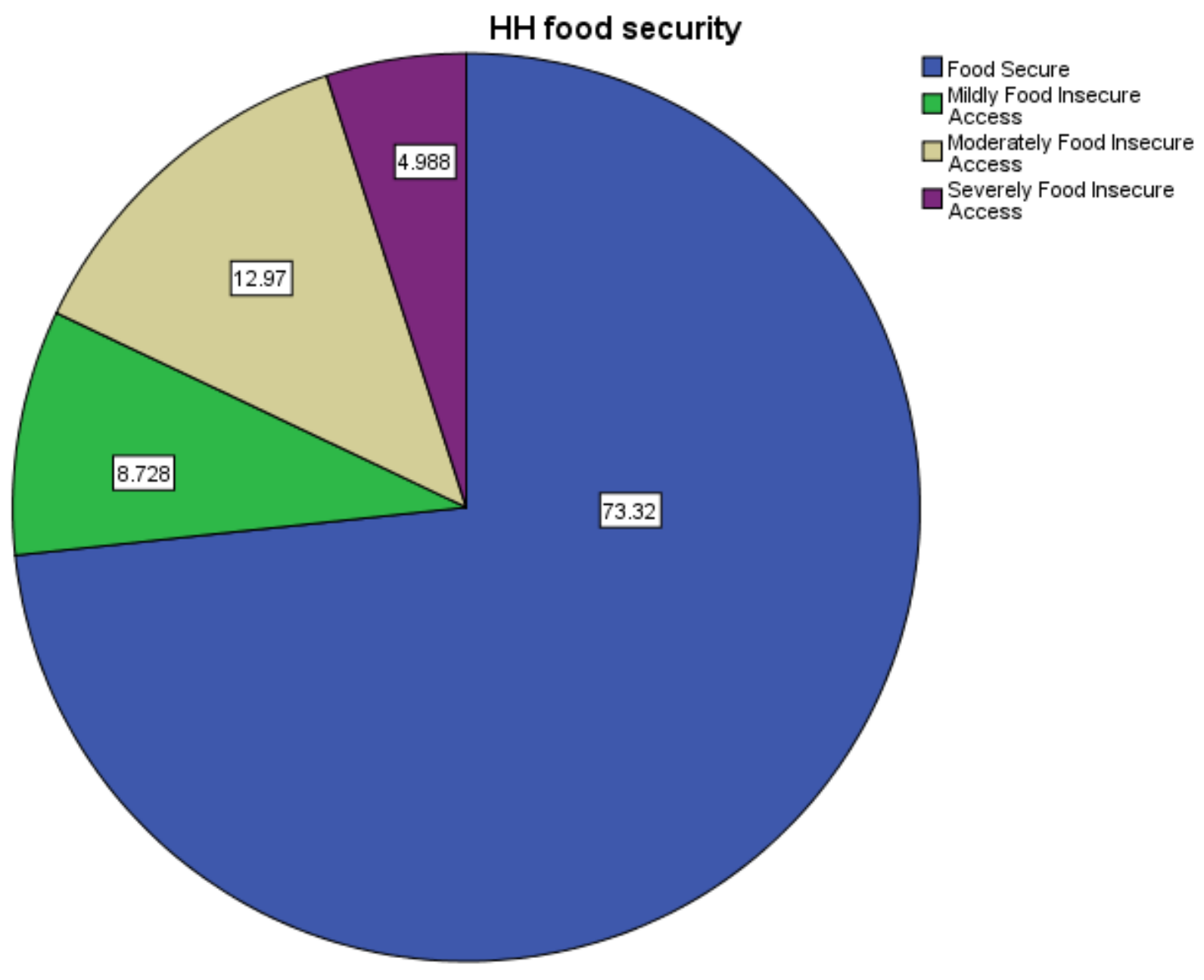

\section{Figure 1}

Household food security levels among the study participants in Dire Dawa town, Eastern Ethiopia, $2019 / 20(n=401)$ 


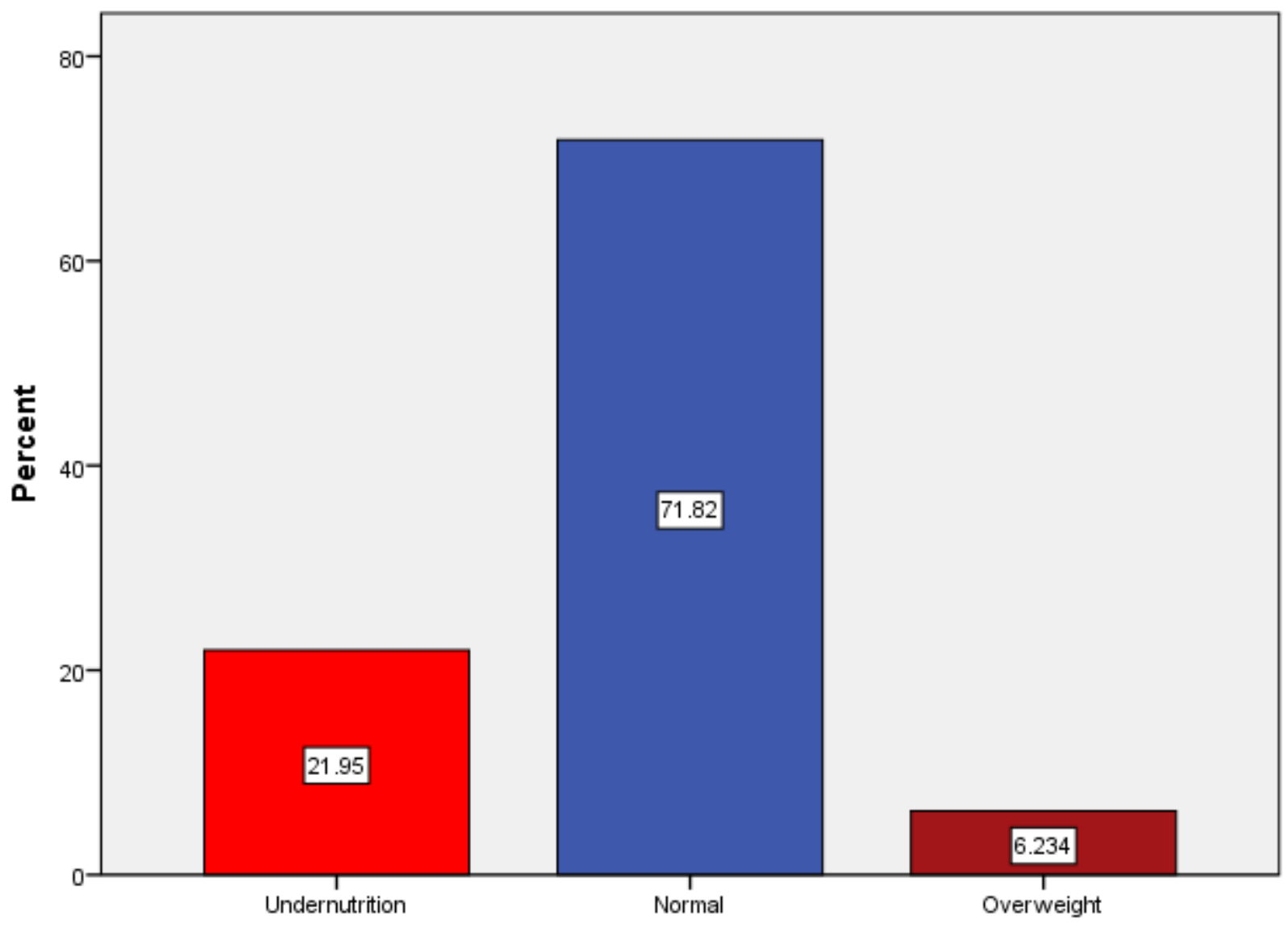

Figure 2

Nutritional status of study participants Using BMI in Dire Dawa town, Eastern Ethiopia, 2019/20 ( $n=401)$ 